\title{
Nocardia neocaledoniensis sp. nov., a novel actinomycete isolated from a New-Caledonian brown hypermagnesian ultramafic soil
}

Correspondence

Michael Goodfellow

m.goodfellow@ncl.ac.uk

\author{
Danielle Saintpierre-Bonaccio, ${ }^{1}$ Luis A. Maldonado, ${ }^{2}$ Hamid Amir, ${ }^{1}$ \\ René Pineau ${ }^{1}$ and Michael Goodfellow ${ }^{2}$
}

\author{
${ }^{1}$ Laboratoire de Biologie et Physiologie Végétales Appliquées, Université de la \\ Nouvelle-Calédonie, BP 4477 98847, Nouméa, New Caledonia \\ ${ }^{2}$ School of Biology, King George Vlth Building, University of Newcastle, Newcastle upon Tyne \\ NE1 7RU, UK
}

The genus Nocardia is well defined, due mainly to the application of chemotaxonomic, molecular systematic and numerical phenetic methods (Goodfellow et al., 1999). At the time of writing, the taxon contains 29 species with validly published names that form a clade within the evolutionary radiation occupied by mycolic-acid-containing actinomycetes classified in the suborder Corynebacterineae Stackebrandt et al. 1997. The genus can be distinguished from the other genera assigned to the suborder by a combination of chemical and morphological properties (Goodfellow et al., 1999). Similarly, Nocardia species can be separated from one another by using a range of phenotypic properties (Yassin et al., 2001; Zhang et al., 2003). The improved classification of the genus is providing an invaluable framework for the recognition of novel Nocardia species, as exemplified by the description of novel species of clinical (Yassin et al., 2000; Hamid et al., 2001), ecological (Chun et al., 1998; Maldonado et al., 2000; Albuquerque de Barros et al., 2003) and industrial (Isik et al., 1999b; Kinoshita et al., 2001) significance.

Ultramafic soils account for about a third of the landmass of the main island of New Caledonia (Jaffré, 1976). There is evidence that these arid, infertile soils, which have high

Published online ahead of print on 31 October 2003 as DOI 10.1099/ ijs.0.02881-0.

Abbreviation: MBA, modified Bennett's agar.

The GenBank/EMBL/DDBJ accession number for the 16S rRNA gene sequence of strain $\mathrm{SBH}_{\mathrm{R}} \mathrm{OA6}{ }^{\top}$ is $\mathrm{AY} 282603$. metal toxicity due to the presence of chromium, cobalt, iron and nickel, provide a rich habitat for unusual actinomycetes of industrial significance (Saintpierre, 2001; Saintpierre et al., 2003; D. Saintpierre-Bonaccio, H. Amir, R. Pineau and $\mathrm{M}$. Goodfellow, unpublished results). During the course of a screening programme designed to isolate novel actinomycetes from New-Caledonian ultramafic soils, an actinomycete, designated $\mathrm{SBH}_{\mathrm{R}} \mathrm{OA6}^{\mathrm{T}}$, was isolated and presumptively assigned to the genus Nocardia (Saintpierre, 2001). The aim of the present study was to establish the taxonomic position of this organism using genotypic and phenotypic procedures. It is evident from the results that the organism represents a novel species in the genus Nocardia, for which the name Nocardia neocaledoniensis sp. nov. is proposed.

Strain $\mathrm{SBH}_{\mathrm{R}} \mathrm{OA6}^{\mathrm{T}}$ was isolated from a suspension of a brown hypermagnesian ultramafic soil that was used to inoculate an oatmeal agar plate (ISP 3 medium; Shirling \& Gottlieb, 1966) supplemented with cycloheximide $\left(100 \mu \mathrm{g} \mathrm{ml}^{-1}\right)$ and incubated at $30^{\circ} \mathrm{C}$ for 10 days. The soil sample was from the 'Plum' region at the southern end of the main island of New Caledonia [see Institut National Geographique, map no. 38 (Mont Dore), 669 ×7536.5, série orange]. The isolate was purified and maintained on modified Bennett's agar (MBA; Jones, 1949) and preserved as a suspension of mycelial fragments in glycerol $(20 \%$, $\mathrm{v} / \mathrm{v})$ at $-20^{\circ} \mathrm{C}$. Biomass for chemotaxonomic studies was prepared by growing the strain in shake flasks of glucose/ yeast extract broth (Gordon \& Mihm, 1962) at 100 r.p.m. for 10 days at $30^{\circ} \mathrm{C}$. Cultures were checked for purity, 
killed by shaking with formalin $(1 \%, \mathrm{v} / \mathrm{v})$, harvested by centrifugation and freeze-dried.

Morphological and staining properties of strain $\mathrm{SBH}_{\mathrm{R}} \mathrm{OA} 6^{\mathrm{T}}$ were detected following growth on MBA plates that had been incubated for 2 weeks at $30^{\circ} \mathrm{C}$. Additional phenotypic properties were determined using well-established methods (Williams et al., 1983; Isik et al., 1999a). Standard procedures were used for the extraction and analysis of mycolic acids (Minnikin et al., 1975), whole-organism sugars (Schaal, 1985) and isoprenoid quinones and polar lipids (Minnikin et al., 1984), using appropriate controls. The isomeric form of diaminopimelic acid $\left(\mathrm{A}_{2} \mathrm{pm}\right)$ was determined after Staneck \& Roberts (1974), using a modified solvent system consisting of methanol/water/ $10 \mathrm{M} \mathrm{HCl} /$ pyridine (85: $15: 5: 10$, by vol.).

Biomass for $16 \mathrm{~S}$ rDNA nucleotide sequencing was obtained by growing strain $\mathrm{SBH}_{\mathrm{R}} \mathrm{OA6}^{\mathrm{T}}$ on an MBA plate for 7 days at $30^{\circ} \mathrm{C}$. Isolation of chromosomal DNA, PCR amplification and direct sequencing of the purified product were carried out as described previously (Kim et al., 1999). The resultant $16 \mathrm{~S}$ rRNA gene sequence was aligned manually with corresponding sequences of representatives of the genera classified in the suborder Corynebacterineae retrieved from the DDBJ/EMBL/GenBank databases using the PHYDIT program (Chun, 1995). Evolutionary trees were inferred using the least-squares (Fitch \& Margoliash, 1967), maximum-parsimony (Kluge \& Farris, 1969) and neighbour-joining (Saitou \& Nei, 1987) treeing algorithms from the PHYLIP suite of programs (Felsenstein, 1993). Evolutionary-distance matrices for the least-squares and neighbour-joining methods were generated after Jukes \& Cantor (1969). The topologies of the resultant trees were evaluated by bootstrap analyses (Felsenstein, 1985) of the neighbour-joining datasets on 1000 resamplings using the SEQBOOT and CONSENSE options from the PHYLIP package. DNA-DNA relatedness values between strain $\mathrm{SBH}_{\mathrm{R}} \mathrm{OA6}^{\mathrm{T}}$ and related strains were determined by the identification service at the Deutsche Sammlung von Mikroorganismen und Zellkulturen (Braunschweig, Germany), as described by Kim et al. (1999).

Strain $\mathrm{SBH}_{\mathrm{R}} \mathrm{OA6}^{\mathrm{T}}$ has phenotypic properties consistent with its classification in the genus Nocardia (Goodfellow et al., 1999). The organism is an aerobic, Gram-positive, partially acid-alcohol-fast actinomycete that forms an extensively branched substrate mycelium that fragments into irregular, rod-shaped, non-motile elements and supports pale-orange aerial hyphae when grown on glucose/ yeast extract agar and MBA plates. The organism was also shown to yield whole-organism hydrolysates rich in meso$\mathrm{A}_{2} \mathrm{pm}$, arabinose and galactose (wall chemotype IV sensu Lechevalier \& Lechevalier, 1970) and to have major proportions of diphosphatidylglycerol, phosphatidylethanolamine, phosphatidylinositol and phosphatidylinositol mannosides (phospholipid type II sensu Lechevalier et al., 1977). It also contained predominant amounts of hexahydrogenated menaquinones with eight isoprene units where the end two were cyclized; this menaquinone is characteristic of the genera Nocardia and Skermania (Chun et al., 1997; Goodfellow et al., 1999). It is also characterized by the presence of mycolic acids that co-migrated $\left(R_{\mathrm{f}}\right.$ value around $0 \cdot 47$ ) with those from marker strains of Nocardia.

The almost complete $16 \mathrm{~S}$ rRNA gene sequence (1474 nt) obtained for strain $\mathrm{SBH}_{\mathrm{R}} \mathrm{OA6}^{\mathrm{T}}$ was compared with sequences of representatives of the suborder Corynebacterineae and found to have the signature sequences expected for members of this taxon and the family Nocardiaceae (Stackebrandt et al., 1997). The high 16S rRNA gene sequence similarities found between the tested strain and representatives of the genus Nocardia (95.4$98.7 \%$ ) support its inclusion in this taxon. The $16 \mathrm{~S}$ rRNA gene sequence of strain $\mathrm{SBH}_{\mathrm{R}} \mathrm{OA}^{\mathrm{T}}$ also has the signature nucleotides characteristic of the genus Nocardia (Chun \& Goodfellow, 1995).

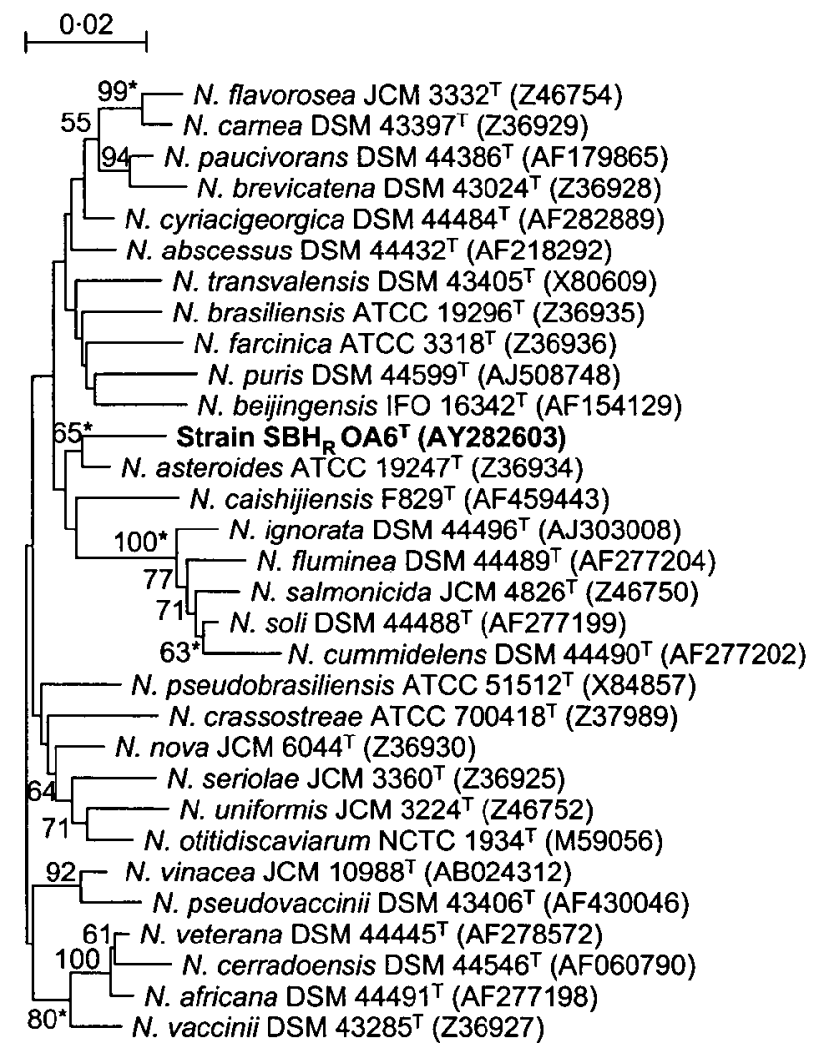

Fig. 1. Neighbour-joining tree (Saitou \& Nei, 1987) based on nearly complete $16 \mathrm{~S}$ rRNA gene sequences showing relationships between strain $\mathrm{SBH}_{\mathrm{R}} \mathrm{OA}^{\top}$ and representatives of Nocardia species. Asterisks indicate branches of the tree that were also found using the least-squares (Fitch \& Margoliash, 1967) and maximum-parsimony (Kluge \& Farris, 1969) treeing algorithms. Numbers at nodes indicate levels of bootstrap support (\%) based on a neighbour-joining analysis of 1000 resampled datasets; only values above $50 \%$ are shown. Bar, 0.02 substitutions per site. 
It is evident from Fig. 1 that strain $\mathrm{SBH}_{\mathrm{R}} \mathrm{OA}^{\mathrm{T}}$ is most closely associated with the type strain of Nocardia asteroides, a relationship that is supported by all of the treeing algorithms and by a moderately high bootstrap value. The two strains share $98.7 \% 16 \mathrm{~S}$ rRNA gene sequence similarity, a value that corresponds to $17 \mathrm{nt}$ differences at 1470 locations. However, it is evident from the DNA-DNA relatedness study that the two strains should not be classified in the same species, as they were found to share $40 \cdot 8 \%$ DNA-DNA relatedness, a value well below the $70 \%$ cut-off point recommended for the delineation of genomic species (Wayne et al., 1987). The organism also has a profile of phenotypic properties that distinguish it from representatives of all species of Nocardia with validly published names, including N. asteroides (Table 1).

The genotypic and phenotypic data indicate that strain $\mathrm{SBH}_{\mathrm{R}} \mathrm{OA6}^{\mathrm{T}}$ merits recognition as a novel species of Nocardia. It is proposed that the organism be classified in the genus Nocardia as Nocardia neocaledoniensis sp. nov.

\section{Description of Nocardia neocaledoniensis sp. nov.}

Nocardia neocaledoniensis (ne.o.ca.le.do.ni.en'sis. N.L. fem. adj. neocaledoniensis pertaining to New Caledonia, the source of the isolate).

Aerobic, Gram-positive, catalase-positive, slightly acidalcohol-fast, non-motile actinomycete that forms an extensively branched orange substrate mycelium that fragments in situ into irregular rod-shaped elements and which carries abundant pale-orange aerial hyphae on MBA. Melanin pigments are produced on peptone/yeast extract/ iron agar. Chemotaxonomic properties are typical of Nocardia. Grows at $10-45^{\circ} \mathrm{C}$ and from $\mathrm{pH} 4$ to 12 . Degrades DNA and Tween 80 but not gelatin, guanine, starch or xylan. Produces hydrogen sulphide. Utilizes (+)-D-fructose, (+)-D-mannose, (+)-D-raffinose and $(+)$-D-trehalose as sole carbon sources for energy and growth but not adonitol, $(-)$-D-arabinose, $(+)$-D-cellobiose, $(+)$-D-galactose, $(+)$-D-lactose, $(+)$-D-maltose, $(+)$-Dmelibiose, $(+)$-D-sucrose (all at $1 \%, \mathrm{w} / \mathrm{v}$ ) or sodium

Table 1. Phenotypic properties that distinguish strain $\mathrm{SBH}_{\mathrm{R}} \mathrm{OA} 6^{\top}$ from the type strains of Nocardia species

Strains: 1, strain $\mathrm{SBH}_{\mathrm{R}} \mathrm{OA6}^{\mathrm{T}}$; 2, N. abscessus DSM 44432 $;$; N. africana DSM 44491 ${ }^{\mathrm{T}} ; 4$, N. asteroides ATCC 19247 ${ }^{\mathrm{T}}$; 5 , N. beijingensis IFO $16342^{\mathrm{T}} ; 6, N$. brasiliensis ATCC $19296^{\mathrm{T}} ; 7$, N. brevicatena DSM 43024 ${ }^{\mathrm{T}} ; 8, N$. caishijiensis JCM $11508^{\mathrm{T}} ; 9, N$. carnea $^{\mathrm{DSM}} 43397^{\mathrm{T}}$; 10 , N. cerradoensis DSM 44546 ${ }^{\mathrm{T}}$; 11, N. crassostreae ATCC $700418^{\mathrm{T}} ; 12, N$. cummidelens DSM $44490^{\mathrm{T}} ; 13$, N. cyriacigeorgica DSM 44484 $4^{\mathrm{T}}$; 14 , N. farcinica ATCC $3318^{\mathrm{T}} ; 15$, N. flavorosea JCM 3332 $; 16, N$. fluminea DSM $44489^{\mathrm{T}} ; 17$, N. ignorata DSM 44496 ${ }^{\mathrm{T}}$; $18, \mathrm{~N}^{\mathrm{T}}$. nova JCM $6044^{\mathrm{T}} ; 19$, N. otitidiscaviarum NCTC $1934^{\mathrm{T}} ; 20$, N. paucivorans DSM 44386 $; 21$, N. pseudobrasiliensis ATCC 51512 ${ }^{\mathrm{T}}$; 22, N. puris DSM $44599^{\mathrm{T}}$; 23, N. salmonicida JCM $4826^{\mathrm{T}}$; 24, N. seriolae JCM $3360^{\mathrm{T}} ; 25$, N. soli DSM $44488^{\mathrm{T}} ; 26$, N. transvalensis DSM 43405 ${ }^{\mathrm{T}}$; $27, \mathrm{~N}$. uniformis JCM $3224^{\mathrm{T}} ; 28$, N. vaccinii DSM $43285^{\mathrm{T}}$; 29, N. veterana DSM $44445^{\mathrm{T}}$; 30, N. vinacea JCM $10988^{\mathrm{T}}$. ND, Not determined; D, doubtful. Data for reference strains were taken from Albuquerque de Barros et al. (2003), Yassin et al. (2003) and Zhang et al. (2003) unless indicated otherwise. All strains are negative for decomposition of $0 \cdot 4 \%$ (w/v) adenine (data for N. cummidelens DSM $44490^{\mathrm{T}}$ from this study).

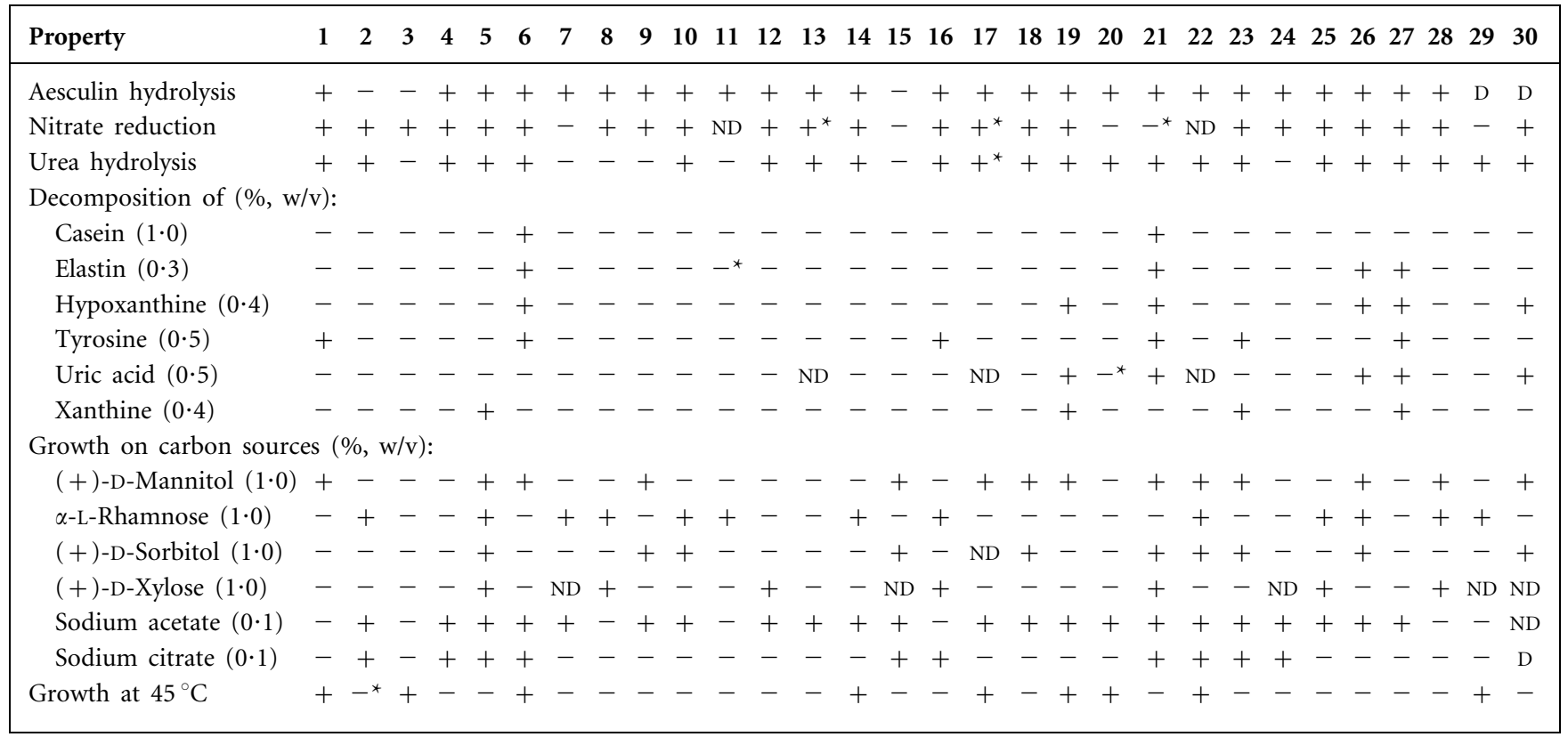

${ }^{\star}$ Data from this study. 
succinate $(0 \cdot 1 \%, \mathrm{w} / \mathrm{v})$. Growth occurs in the presence of erythromycin $\left(4 \mu \mathrm{g} \mathrm{ml}^{-1}\right)$, gentamicin sulphate $\left(10 \mu \mathrm{g} \mathrm{ml}^{-1}\right)$, penicillin $\mathrm{G}\left(25 \mu \mathrm{g} \mathrm{ml}^{-1}\right)$, rifampicin $\left(6 \mu \mathrm{g} \mathrm{ml}^{-1}\right)$, streptomycin sulphate $\left(5 \mu \mathrm{g} \mathrm{ml}^{-1}\right)$, vancomycin hydrochloride $\left(10 \mu \mathrm{g} \mathrm{ml}^{-1}\right)$, crystal violet $(0 \cdot 0002 \%$, w/v), phenol $(0.01 \%, \mathrm{w} / \mathrm{v})$ and sodium chloride $(3 \%, \mathrm{w} / \mathrm{v})$, but not in the presence of tetracycline hydrochloride $\left(30 \mu \mathrm{g} \mathrm{ml}^{-1}\right)$, potassium tellurite $(0 \cdot 005 \%, \mathrm{w} / \mathrm{v})$ or $5 \%(\mathrm{w} / \mathrm{v})$ sodium chloride. Additional phenotypic properties are shown in Table 1 . The species description is based on a single strain, which hence serves as the type strain.

The type strain, $\mathrm{SBH}_{\mathrm{R}} \mathrm{OA6}^{\mathrm{T}}\left(=\mathrm{DSM} 44717^{\mathrm{T}}=\mathrm{NCIMB}\right.$ $13955^{\mathrm{T}}$ ), was isolated from a brown hypermagnesian ultramafic soil at the southern end of the main island of New Caledonia.

\section{Acknowledgements}

H. A., R. P. and D. S.-B. are indebted to la Direction des Ressources Naturelles (DRN) de la Province Sud de la Nouvelle-Calédonie for financing the project.

\section{References}

Albuquerque de Barros, E. V. S., Manfio, G. P., Ribeiro Maitan, V., Mendes Bataus, L. A., Kim, S. B., Maldonado, L. A. \& Goodfellow, M. (2003). Nocardia cerradoensis sp. nov., a novel isolate from Cerrado soil in Brazil. Int J Syst Evol Microbiol 53, 29-33.

Chun, J. (1995). Computer-assisted classification and identification of actinomycetes. $\mathrm{PhD}$ thesis, University of Newcastle, Newcastle upon Tyne, UK.

Chun, J. \& Goodfellow, M. (1995). A phylogenetic analysis of the genus Nocardia with $16 \mathrm{~S}$ rRNA gene sequences. Int J Syst Bacteriol 45, 240-245.

Chun, J., Blackall, L. L., Kang, S.-O., Hah, Y. C. \& Goodfellow, M. (1997). A proposal to reclassify Nocardia pinensis Blackall et al. as Skermania piniformis gen. nov., comb. nov. Int J Syst Bacteriol 47, 127-131.

Chun, J., Seong, C.-N., Bae, K. S., Lee, K.-J., Kang, S.-O., Goodfellow, M. \& Hah, Y. C. (1998). Nocardia flavorosea sp. nov. Int J Syst Bacteriol 48, 901-905.

Felsenstein, J. (1985). Confidence limits on phylogenies: an approach using the bootstrap. Evolution 39, 783-791.

Felsenstein, J. (1993). PHYLIP (Phylogenetic Inference Package), version 3.5c. Department of Genetics, University of Washington, Seattle, USA.

Fitch, W. M. \& Margoliash, E. (1967). Construction of phylogenetic trees: a method based on mutation distances as estimated from cytochrome $c$ sequences is of general applicability. Science 155, 279-284.

Goodfellow, M., Isik, K. \& Yates, E. (1999). Actinomycete systematics: an unfinished synthesis. Nova Acta Leopold 312 (NF80), 47-82.

Gordon, R. E. \& Mihm, J. M. (1962). Identification of Nocardia caviae (Erikson) nov. comb. Ann N Y Acad Sci 98, 628-636.

Hamid, M. E., Maldonado, L., Sharaf Eldin, G. S., Mohamed, M. F., Saeed, N. S. \& Goodfellow, M. (2001). Nocardia africana sp. nov., a new pathogen isolated from patients with pulmonary infections. J Clin Microbiol 39, 625-630.

Isik, K., Chun, J., Hah, Y. C. \& Goodfellow, M. (1999a). Nocardia salmonicida nom. rev., a fish pathogen. Int J Syst Bacteriol 49, 833-837.
Isik, K., Chun, J., Hah, Y. C. \& Goodfellow, M. (1999b). Nocardia uniformis nom. rev. Int J Syst Bacteriol 49, 1227-1230.

Jaffré, T. (1976). Composition clinique et conditions de l'alimentation minérale des plantes sur roches ultrabasiques. Cah ORSTOM Ser Biol 11, 53-63 (in French).

Jones, K. L. (1949). Fresh isolates of actinomycetes in which the presence of sporogenous aerial mycelia is a fluctuating characteristic. J Bacteriol 57, 141-145.

Jukes, T. H. \& Cantor, C. R. (1969). Evolution of protein molecules. In Mammalian Protein Metabolism, vol. 3, pp. 21-132. Edited by H. N. Munro. New York: Academic Press.

Kim, S. B., Brown, R., Oldfield, C., Gilbert, S. C. \& Goodfellow, M. (1999). Gordonia desulfuricans sp. nov., a benzothiophenedesulphurizing actinomycete. Int J Syst Bacteriol 49, 1845-1851.

Kinoshita, N., Homma, Y., Igarashi, M., Ikeno, S., Hori, M. \& Hamada, M. (2001). Nocardia vinacea sp. nov. Actinomycetologica $15,1-5$.

Kluge, A. G. \& Farris, F. S. (1969). Quantitative phyletics and the evolution of anurans. Syst Zool 18, 1-32.

Lechevalier, M. P. \& Lechevalier, H. (1970). Chemical composition as a criterion in the classification of aerobic actinomycetes. Int J Syst Bacteriol 20, 435-443.

Lechevalier, M. P., De Bièvre, C. \& Lechevalier, H. A. (1977). Chemotaxonomy of aerobic actinomycetes: phospholipid composition. Biochem Syst Ecol 5, 249-260.

Maldonado, L., Hookey, J. V., Ward, A. C. \& Goodfellow, M. (2000). The Nocardia salmonicida clade, including descriptions of Nocardia cummidelens sp. nov., Nocardia fluminea sp. nov. and Nocardia soli sp. nov. Antonie van Leeuwenhoek 78, 367-377.

Minnikin, D. E., Alshamaony, L. \& Goodfellow, M. (1975). Differentiation of Mycobacterium, Nocardia, and related taxa by thin-layer chromatographic analysis of whole-organism methanolysates. J Gen Microbiol 88, 200-204.

Minnikin, D. E., O’Donnell, A. G., Goodfellow, M., Alderson, G., Athalye, M., Schaal, A. \& Parlett, J. H. (1984). An integrated procedure for the extraction of bacterial isoprenoid quinones and polar lipids. J Microbiol Methods 2, 233-241.

Saintpierre, D. (2001). Identification de souches originales d'actinomycétes isolées de sols ultramafiques de Nouvelle-Calédonie. Caractérisation chimique de quelques antibiotiques produits. $\mathrm{PhD}$ thesis, Institut National Polytechnique de Toulouse, France (in French).

Saintpierre, D., Amir, H., Pineau, R., Sembiring, L. \& Goodfellow, M. (2003). Streptomyces yatensis sp. nov., a novel bioactive streptomycete isolated from a New-Caledonian ultramafic soil. Antonie van Leeuwenhoek 83, 21-26.

Saitou, N. \& Nei, M. (1987). The neighbor-joining method: a new method for reconstructing phylogenetic trees. Mol Biol Evol 4, 406-425.

Schaal, K. P. (1985). Laboratory diagnosis of actinomycete diseases. In Chemical Methods in Bacterial Systematics, pp. 359-381. Edited by M. Goodfellow \& D. E. Minnikin. London: Academic Press.

Shirling, E. B. \& Gottlieb, D. (1966). Methods for characterization of Streptomyces species. Int J Syst Bacteriol 16, 313-340.

Stackebrandt, E., Rainey, F. A. \& Ward-Rainey, N. L. (1997). Proposal for a new hierarchic classification system, Actinobacteria classis nov. Int J Syst Bacteriol 47, 479-491.

Staneck, J. L. \& Roberts, G. D. (1974). Simplified approach to identification of aerobic actinomycetes by thin-layer chromatography. Appl Microbiol 28, 226-231.

Wayne, L. G., Brenner, D. J., Colwell, R. R. \& 9 other authors (1987). Report of the ad hoc committee on reconciliation of approaches to bacterial systematics. Int J Syst Bacteriol 37, 463-464. 
Williams, S. T., Goodfellow, M., Alderson, G., Wellington, E. M. H., Sneath, P. H. A. \& Sackin, M. J. (1983). Numerical classification of Streptomyces and related genera. J Gen Microbiol 129, 1743-1813.

Yassin, A. F., Rainey, F. A., Mendrock, U., Brzezinka, H. \& Schaal, K. P. (2000). Nocardia abscessus sp. nov. Int J Syst Evol Microbiol 50, 1487-1493.
Yassin, A. F., Rainey, F. A. \& Steiner, U. (2001). Nocardia ignorata sp. nov. Int J Syst Evol Microbiol 51, 2127-2131.

Yassin, A. F., Sträubler, B., Schumann, P. \& Schaal, K. P. (2003).

Nocardia puris sp. nov. Int J Syst Evol Microbiol 53, 1595-1599.

Zhang, J., Liu, Z. \& Goodfellow, M. (2003). Nocardia caishijiensis sp. nov., a novel soil actinomycete. Int J Syst Evol Microbiol 53, 999-1004. 